\title{
Adversity Quotients Towards Achievement Motivation of Early Childhood Teacher Education (PG PAUD) Students in Bali
}

\author{
Dewa Gede Firstia Wirabrata ${ }^{1 *}$, Dewa Ayu Puteri Handayani ${ }^{1}$ \\ ${ }^{1}$ Universitas Pendidikan Ganesha \\ "Corresponding author. Email: firstia.wirabrata@undiksha.ac.id
}

\begin{abstract}
This study aims to investigate the effect of Adversity Quotients (AQ) on Achievement Motivation in Early Childhood Teacher Education (PG PAUD) students in Bali. This research uses quantitative research approach using two variables, $\mathrm{AQ}$ and Achievement Motivation. AQ defined as the ability or capacity of a person in controlling and directing desires and responding to existing challenges while Achievement Motivation defined as a person's ability/capacity to direct their behavior towards achievement. The AQ variable was measured using the Adversity Response Profile (ARP) while the Achievement Motivation variable was measured using the Achievement Motivation Scale (AMS). The population of this study was PG PAUD students in Bali with research sample taken using simple random sampling technique. This research produced outcomes in the form of proceedings as well as an effort to enrich textbooks. Another benefit of this research was that it provided an overview of AQ related to its influence on Achievement Motivation so that later AQ training efforts can be made in order to optimize Achievement Motivation of PG PAUD students in order to fulfill the vision and profile of graduates to produce superior scholars. Result shows that there's no effect between AQ and Achievement Motivation towards PG PAUD students in Bali.
\end{abstract}

\section{Keywords: Achievement Motivation, Adversity Quotients (AQ), Early Childhood Teacher Education Students (PG PAUD)}

\section{INTRODUCTION}

The world continues to move forward and offers so many opportunities but also new challenges that must be faced by students, no exception. Nowadays it is increasingly clear that in order to achieve success, it is not enough for students to only learn passively in class but to be active in exploring other knowledge independently. Passive learning in the classroom will only have a superficial impact on knowledge [1], so that it is time for students to develop a higher desire to seek knowledge in order to achieve an achievement. The desire to achieve an achievement is called achievement motivation. Achievement motivation directs human behavior towards an achievement so that it is considered an important factor that determines a person's success[2]. One of the achievement motivations that is interesting to examine is the achievement motivation in the Early Childhood Education Teacher Education (PG PAUD) student community in Bali The interesting point of this community is that there is an indication of the low achievement motivation that exists in each individual, which is in contrast to the profile of graduates and the vision of PG PAUD faculties in across Bali which intend to have superior graduates. Indications of low achievement motivation are obtained based on direct observations that occur in classroom learning. From the observation, it appears that PG PAUD students are mostly silent even though they were given the opportunity to speak. Likewise, when they were asked questions, they were less enthusiastic about answering. The results of this observation were confirmed by conducting interviews with a number of teaching staff at the PG PAUD lecturers. The results of the interview indicated the same thing, namely that students seemed to have no motivation to score an achievement which was marked by being easily bored and tired of participating in learning, a posture that seemed less enthusiastic and also easily discouraged when given challenges in the form of critical questions. From the data obtained, the indication is getting stronger that the achievement motivation of PG PAUD students in Bali is currently not optimal. 
The existence of achievement motivation is strongly influenced by many factors, such as motivational beliefs, task values, goals and achievement motives [3];[4]. However, there are still very few studies investigating the relationship between achievement motivation and these factors [5]. [3] Found a strong attachment between achievement motivation and self-concept where the selfconcept in question is the belief to be able to direct oneself towards an achievement and also a belief in one's ability to overcome obstacles in the process of achieving an achievement. Both of these self-concepts can be found in Paul G. Stoltz's theory of Adversity Quotient (AQ). [6] Defines AQ as the ability to control and direct desires and control adversity in the form of obstacles and disadvantages. In several studies that have been conducted and using thousands of participants around the world, it is found that AQ is one of the crucial factors that determine a person's success. AQ moves a person to achieve success where the higher a person's AQ, the greater the person's ability to face obstacles and advance to achieve what he wants [6]. The AQ study that has been conducted in Indonesia in [7] found the fact that AQ has a significant role in student's achievement. Based on the description above and strong relationship between AQ and achievement motivation, this time the researcher intends to see how AQ influences student achievement motivation, especially on PG PAUD students in Bali.

\section{RESEARCH METHODS}

The research approach used in this research is quantitative research approach. The quantitative research approach is one type of research which specifications are systematic, well-planned and clearly structured from the start to the making of the research design. This research is a correlational study and seen from the data collected. This research is an ex post facto study where the data collected is data as is without giving control, treatment, or manipulation [8]. This ex post facto study involved two variables, namely AQ with Achievement Motivation. This research conducted in Bali. [6] Defines AQ as a person's ability or capacity to control and direct desires and respond to existing challenges. AQ has four dimensions namely (CO2RE) namely Control, Origin and Ownership, Reach, Endurance. Operational definition of AQ in this study is the total AQ score measured using the Adversity Response Profile (ARP) which was first developed in 1997 by Dr. Paul G. Stoltz. Meanwhile, achievement motivation is defined as a person's ability/capacity to direct their behavior towards achievement [4]. The operational definition of Achievement Motivation in this study is the total score of achievement motivation measured using the Achievement Motivation Scale. The study population is a group of individuals who have the same characteristics [9]. For this research, the population is all PG PAUD students in Bali. From this population, samples were taken. According to [9], the sample is part of the population that the researcher wants to examine, the results will be generalized to the population. The sampling technique used in this study was simple random sampling. To select the sample of this study randomly, subject selection was carried out using a random table [10]. The sample size is determined using the Slovin formula. Slovin formula is as follows:

$$
\begin{gathered}
n=\frac{N}{1+\left(N \times e^{2}\right)} \\
\mathrm{n} \quad: \quad \text { Sample Size } \\
\mathrm{N} \quad: \quad \text { Population } \\
\mathrm{e} \quad: \quad \text { Tolerance }
\end{gathered}
$$

Data collection in this study was using a questionnaire. Data were collected using a questionnaire because some of the advantages of the questionnaire which are questionnaire has been used widely and is a very useful instrument in information-gathering surveys, able providing structured numerical data and can be done without the presence of researchers [8] Collecting data in this study using two questionnaires; one questionnaire to measure AQ and the other questionnaire measure Achievement Motivation. Instrument for measuring AQ used in this study is Stoltz's Adversity Response Profile (in the Indonesian-language printed book 2000). Researcher then looks for several ratings to see the suitability of grammar where the words are not suitable or the words according to rater will be difficult to be understood by the subject will be revised. Meanwhile, the Achievement Motivation questionnaire in this study uses the Achievement Motivation Scale which will be back translated before use.

\section{RESULTS AND DISCUSSIONS}

This study involved 120 female participants and only 7 male participants. The results of the analysis using the regression analysis method showed a significance result of 0.074 (above 0.005 ) which indicated that there was no influence between AQ and Achievement Motivation. This study shows an interesting result in which large variables which are suspected of having an influence on one another are found to have no effect. These results lead us to re-examine the phenomenon to obtain a logical explanation regarding the results obtained. Similar research results were found in research [11] where there was a positive relationship between AQ and Achievement Motivation but the relationship was very small. AQ as we re-examine the definition, is the ability to come back from failure, in the sense that someone with high AQ will be able to easily return to a normal state when facing obstacles or challenges. The return of a person to their normal state does not necessarily increase their desire or motivation to get more results or achievements than what they have previously set. This helps us to explain why AQ has no influence on one's 
achievement motivation, especially in the context of PG PAUD students in Bali. Another explanation is related to gender. In [12] found that women have a lower achievement motivation than men but on the different side have higher resistance to problems. Women will find it easier to return to their normal state when facing problems, even though their achievement motivation tends to be low, at least lower than men. These findings support the results of this study where most of the participants were female, so it is true, at least for female gender, AQ (resistance to problems) does not automatically affect achievement motivation.

\section{CONCLUSION}

Based on the results obtained through this research, it can be concluded that there is no influence between AQ and Achievement Motivation of Early Childhood Education Teacher Education (PAUD) students in Bali. The explanation for this is due to gender as well as because a person's resilience does not necessarily mean that they have a higher desire for achievement than the standards they have previously set. This study used early childhood teacher education (PAUD) students in Bali, where almost all of them were female. For future researchers, participants can be used with a more proportional ratio between male and female. Further researchers can also re-investigate this variable by linking it with other variables such as future orientation variables, expectations, and self-concept.

\section{REFERENCES}

[1] D. Perkins, Constructivism and troublesome knowledge, Overcoming barriers to student understanding: Threshold concepts and troublesome knowledge, 2006, pp 33-47.

[2] I. Plante, P. A. O'Keefe, and M. Théorêt, The relation between achievement goal and expectancyvalue theories in predicting achievement-related outcomes: a test of four theoretical conceptions, Motiv. Emot. 37, 2013, pp 65-78. Doi: 10.1007/s1 1031-012-9282-9

[3] A. Wigfield, and J. Cambria, Students' achievement values, goal orientations, and interest: definitions, development, and relations to achievement outcomes, Dev. Rev. 30, 2010, pp 1-35. Doi: 10.1016/j.dr.2009.12.001

[4] A. Wigfield, S. Tonks, and S. L. Klauda, "Expectancy-value theory," in Handbook of Motivation in School, 2nd Edn. eds K. R. Wentzel and D. B. Mielecpesnm, New York, NY: Routledge, 2016. pp 55-74

[5] K. Kriegbaum, M. Jansen, and B. Spinath, Motivation: a predictor of PISA's mathematical competence beyond intelligence and prior test achievement, Learn. Individ. Differ, 43, 2015. Pp 140-148. Doi: 10.1016/j.lindif.2015.08.026

[6] P. G. Stoltz, Adversity quotient: Mengubah hambatan menjadi peluang, Jakarta: Gramedia Widiarsana Indonesia, 2000.

[7] W. Hidayat, \& R. Sariningsih, Kemampuan pemecahan masalah matematis dan adversity quotient siswa SMP melalui pembelajaran open ended, 2(1), (2018), pp 109-118

[8] L. Cohen, L. Manion, and K. Morrison, Research methods in education, Routledge, Oxon, 2007.

[9] J.W. Creswell, Educational research: Planning, conducting, and cvaluating quantitative and qualitative research third edition, United States: Pearson Education Inc, 2008.

[10] S. K. Thompson, Sampling second edition, New York: John Wiley \& Sons. Inc, 2002.

[11] A. L. Guillian, C. J. A. Cornista. Macasaet. Adversity Quotient ${ }^{\circledR}$ And Achievement Motivation Of Selected Third Year And Fourth Year Psychology Students of De La Salle Lipa A.Y, 2012.

[12] B. A. Greene, T. K. Debacker, Gender and orientations toward the future: Links to motivation, In: Education psychology review, Vol. 16, No. 2, 2004, pp. 91-105. 